\title{
Is N95 face mask linked to dizziness and headache?
}

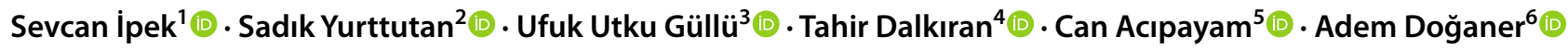

Received: 10 August 2020 / Accepted: 4 February 2021 / Published online: 1 March 2021

(c) The Author(s), under exclusive licence to Springer-Verlag GmbH, DE part of Springer Nature 2021

\begin{abstract}
Objectives During the COVID-19 pandemic, healthcare professionals are recommended to use PPE to prevent the transmission of disease. Healthcare workers who use N95 FFR, which has an important place, experience complaints such as headache and dizziness. In this study, we plan to find the cause of these complaints and aim to clarify whether they are associated with the use of N95 mask.

Method Healthcare workers first put on a surgical mask for at least $1 \mathrm{~h}$ and a maximum of $4 \mathrm{~h}$, this process was then repeated on another day with the same workers wearing N95 masks. After removing the mask, capillary blood gases were taken and a questionnaire was given.

Results Thirty-four participants over the age of 18 were included in the study; 19 participants were female (56\%) and 15 male (44\%). The results of the capillary blood gas analysis after the use of surgical mask and N95 mask, respectively: $\mathrm{pH}: 7.43 \pm 0.03 ; 7.48 \pm 0.04(p<0.001) ; p \mathrm{CO}_{2}: 37.33 \pm 8.81 ; 28.46 \pm 7.77 \mathrm{mmHg}(p<0.001) ; \mathrm{HCO}_{3}: 24.92 \pm 2.86$; $23.73 \pm 3.29 \mathrm{mmol} / \mathrm{L}(p=0.131)$; Base excess $(\mathrm{BE}): 1.40(-3.90-3.10) ;-2.68(-4.50-1.20)$ [median $(\mathrm{Q} 1-\mathrm{Q} 3)](p=0.039)$; lactate: $1.74 \pm 0.68 ; 1.91 \pm 0.61(p=0314)$. Headache, attention deficit and difficulty in concentrating were significantly higher after using N95 mask.

Conclusion Respiratory alkalosis and hypocarbia were detected after the use of N95. Acute respiratory alkalosis can cause headache, anxiety, tremor, muscle cramps. In this study, it was quantitatively shown that the participants' symptoms were due to respiratory alkalosis and hypocarbia.
\end{abstract}

Keywords Dizziness $\cdot$ Headache $\cdot$ N95 mask $\cdot$ Respiratory alkalosis $\cdot$ Surgical mask

Sevcan İpek

drsevcanipek@gmail.com

Sadık Yurttutan

dryurttutan@gmail.com

Ufuk Utku Güllü

ufukutkugullu@gmail.com

Tahir Dalkıran

tahirdalkiran@hotmail.com

Can Acipayam

cacipayam@hotmail.com

Adem Doğaner

adem_doganer@hotmail.com

1 Department of Pediatrics, Kahramanmaraş Sütçü İmam University Medical Faculty, Kahramanmaraş, Turkey
2 Departments of Pediatrics and Neonatal Intensive Care Unit, Kahramanmaraş Sütçü İmam University Medical Faculty, Kahramanmaraş, Turkey

3 Departments of Pediatrics and Pediatric Cardiology, Kahramanmaraş Sütçü İmam University Medical Faculty, Kahramanmaraş, Turkey

4 Department of Pediatric Intensive Care Unit, Kahramanmaraş Necip Fazıl City Hospital, Kahramanmaraş, Turkey

5 Departments of Pediatric Hematology and Oncology, Kahramanmaraş Sutcu Imam University Faculty of Medicine, Kahramanmaraş, Turkey

6 Departments of Biostatistics and Medical Informatics, Kahramanmaraş Sutcu Imam University Faculty of Medicine, Kahramanmaraş, Turkey 


\section{Introduction}

COVID-19 is a disease that manifests as severe acute respiratory syndrome and is caused by a new coronavirus (SARS-CoV-2). It was initially described as an outbreak of respiratory disease in the city of Wuhan in the Hubei province of China (Li et al. 2020). The WHO declared the COVID-19 epidemic a public health emergency on 30 January 2020 and subsequently declared it a pandemic as of March 11, 2020 (Cucinotta and Vanelli 2020; Sohrabi et al. 2020). The transmission is said to be from person to person through droplets or by contact with the mouth and nasal mucosa after touching contaminated areas ( $\mathrm{Li}$ et al. 2020). Healthcare professionals are recommended to use personal protective equipment (PPE) to prevent disease. N95 filtering facepiece respirator (FFR) and surgical masks are common pieces of personal protective equipment (WHO 2020). In the literature, a few quantitative studies have been conducted on the physiological effects of respirator use in healthcare professionals. These studies are generally conducted in the form of a questionnaire.

During the pandemic, we observed that healthcare workers using N95 masks in our hospital had various complaints including headache and dizziness, and one healthcare worker even experienced a syncope following the use of an N95 mask. Some hospital personnel expressed feeling like they will die after using an N95 mask. They also stated that they had difficulty focusing on their work and paying attention. The objective of this study was to identify the reason behind these complaints and whether they are related to the use of an N95 mask.

\section{Materials and methods}

\section{Subjects}

This study was carried out in a university hospital, a tertiary healthcare institution. The study was conducted with consent from the local ethics committee (decision no: 14 sessions: 2020/08). The population of the study consisted of healthcare workers. An informed consent form was filled out by the volunteers. For sample size; using $\mathrm{G}^{*}$ Power 3.1.9.4 software, considering an effect size of 0.8 with a minimum of $80 \%$ power and a $95 \%$ confidence interval, the minimum number of participants was calculated as 34 with a $5 \%$ type 1 error. All healthcare workers included in the study were over the age of 18. The exclusion criteria for the study included the presence of allergic rhinitis, migraine, cluster type headache, tension headache, heart disease, hypertension, diabetes, anxiety disorder, and pregnancy.
The study was conducted with healthcare professionals who provide care to patients without COVID-19 disease in non-COVID-19 wards. In accordance with the policy of our hospital, full PPE should be worn in COVID-19 wards. Outside of COVID-19 wards, healthcare workers must wear either a surgical mask or an N95 mask. And there is an obligation to wear scrubs as clothing. The healthcare professionals we included in our study wore surgical/N95 masks and also wore scrubs.

The ambient temperature of the healthcare environment is regulated by the hospital air conditioning automation. In accordance with the quality standards, the temperature of the intensive care wards in our hospital must be adjustable between 18 and $26^{\circ} \mathrm{C}$ and the relative humidity between 30 and $60 \%$. During operation, ward temperatures were between 24 and $26{ }^{\circ} \mathrm{C}$ and between 30 and $40 \%$ at humidity.

\section{Data collection}

The questionnaire form used was developed in accordance with the literature based on the complaints of the volunteers (Tables 1 and 2) (Atay and Cura 2020). 19 complaints with multiple choices were listed and the time of the complaint(s) was noted. Accordingly, (1) demographic data such as age, gender, occupation, (2) physical symptoms such as headache, dizziness, palpitations, difficulty breathing, (3) psychosomatic symptoms such as feeling of death, attention deficit, concentration problems and fatigue were questioned.

The study was carried out in two phases. (1) Participants wore a surgical mask for a minimum of $1 \mathrm{~h}$ and a maximum of $4 \mathrm{~h}$, after which capillary blood gas was taken and a questionnaire was given. (2) The same participants wore N95 masks for at least $1 \mathrm{~h}$ and at most $4 \mathrm{~h}$ on another day, capillary blood gas was then collected and a questionnaire was given. An N95 (3M 8210) mask and surgical mask of the same standard were used by each participant (EN 2011). The moment blood gases were taken, the Radiometer ABL800 FLEX blood gas analyzer was operated.

\section{Statistical analysis}

In the statistical analysis of data, the conformity of the variables to normal distribution was examined with the Shapiro-Wilk test. Paired $t$ test was used to compare paired measurements in variables with normal distribution. The Wilcoxon test was utilized for variables that did not show normal distribution. The McNemar test was used to compare the frequency distributions of paired measurements. Statistical parameters were expressed as mean \pm SD, median $(25 \%$ quartile-75\% quartile) and $n(\%)$. Statistical significance was accepted as $p<0.05$. The data were evaluated with IBM SPSS Statistics version 22.0 (IBM SPSS for Windows 
Table 1 The survey and capillary blood gas after N95 mask

\begin{tabular}{|c|c|c|c|c|c|}
\hline \multirow{2}{*}{$\begin{array}{l}\text { Volunteer no } \\
\text { Capillary blood gas after N95 mask }\end{array}$} & \multirow{2}{*}{$\begin{array}{l}\text { Weight } \\
\mathrm{pH}\end{array}$} & \multirow{2}{*}{$\begin{array}{l}\text { Height } \\
p \mathrm{CO}_{2}\end{array}$} & \multicolumn{3}{|c|}{ Occupation: (1) doctor (2) nurse (3)staph } \\
\hline & & & $\mathrm{HCO}_{3}$ & $\mathrm{BE}$ & lactate \\
\hline \multirow[t]{2}{*}{ Headache } & (a) Yes & & & & (b) $\mathrm{No}$ \\
\hline & (1) $15 \mathrm{~min}$ & (2) $30 \mathrm{~min}$ & (3) $60 \mathrm{~min}$ & (4) in longer time & \\
\hline \multirow[t]{2}{*}{ Dizziness } & (a) Yes & & & & (b) $\mathrm{No}$ \\
\hline & (1) $15 \mathrm{~min}$ & (2) $30 \mathrm{~min}$ & (3) $60 \mathrm{~min}$ & (4) in longer time & \\
\hline \multirow[t]{2}{*}{ Palpitation } & (a) Yes & & & & (b) $\mathrm{No}$ \\
\hline & (1) $15 \mathrm{~min}$ & (2) $30 \mathrm{~min}$ & (3) $60 \mathrm{~min}$ & (4) in longer time & \\
\hline \multirow[t]{2}{*}{ Difficulty breathing } & (a) Yes & & & & (b) $\mathrm{No}$ \\
\hline & (1) $15 \mathrm{~min}$ & (2) $30 \mathrm{~min}$ & (3) $60 \mathrm{~min}$ & (4) in longer time & \\
\hline \multirow[t]{2}{*}{ Drowsiness } & (a) Yes & & & & (b) $\mathrm{No}$ \\
\hline & (1) $15 \mathrm{~min}$ & (2) $30 \mathrm{~min}$ & (3) $60 \mathrm{~min}$ & (4) in longer time & \\
\hline \multirow[t]{2}{*}{ Pins and needle } & (a) Yes & & & & (b) $\mathrm{No}$ \\
\hline & (1) $15 \mathrm{~min}$ & (2) $30 \mathrm{~min}$ & (3) $60 \mathrm{~min}$ & (4) in longer time & \\
\hline \multirow[t]{2}{*}{ Muscle cramps } & (a) Yes & & & & (b) $\mathrm{No}$ \\
\hline & (1) $15 \mathrm{~min}$ & (2) $30 \mathrm{~min}$ & (3) $60 \mathrm{~min}$ & (4) in longer time & \\
\hline \multirow[t]{2}{*}{ Nausea } & (a) Yes & & & & (b) $\mathrm{No}$ \\
\hline & (1) $15 \mathrm{~min}$ & (2) $30 \mathrm{~min}$ & (3) $60 \mathrm{~min}$ & (4) in longer time & \\
\hline \multirow[t]{2}{*}{ Vomiting } & (a) Yes & & & & (b) $\mathrm{No}$ \\
\hline & (1) $15 \mathrm{~min}$ & (2) $30 \mathrm{~min}$ & (3) $60 \mathrm{~min}$ & (4) in longer time & \\
\hline \multirow[t]{2}{*}{ Facial sweating } & (a) Yes & & & & (b) $\mathrm{No}$ \\
\hline & (1) $15 \mathrm{~min}$ & (2) $30 \mathrm{~min}$ & (3) $60 \mathrm{~min}$ & (4) in longer time & \\
\hline \multirow[t]{2}{*}{ Drowning sense } & (a) Yes & & & & (b) $\mathrm{No}$ \\
\hline & (1) $15 \mathrm{~min}$ & (2) $30 \mathrm{~min}$ & (3) $60 \mathrm{~min}$ & (4) in longer time & \\
\hline \multirow[t]{2}{*}{ Facial ichting } & (a) Yes & & & & (b) $\mathrm{No}$ \\
\hline & (1) $15 \mathrm{~min}$ & (2) $30 \mathrm{~min}$ & (3) $60 \mathrm{~min}$ & (4) in longer time & \\
\hline \multirow[t]{2}{*}{ Coughing } & (a) Yes & & & & (b) $\mathrm{No}$ \\
\hline & (1) $15 \mathrm{~min}$ & (2) $30 \mathrm{~min}$ & (3) $60 \mathrm{~min}$ & (4) in longer time & \\
\hline \multirow[t]{2}{*}{ Sneeze } & (a) Yes & & & & (b) $\mathrm{No}$ \\
\hline & (1) $15 \mathrm{~min}$ & (2) $30 \mathrm{~min}$ & (3) $60 \mathrm{~min}$ & (4) in longer time & \\
\hline \multirow[t]{2}{*}{ Attention deficit } & (a) Yes & & & & (b) $\mathrm{No}$ \\
\hline & (1) $15 \mathrm{~min}$ & (2) $30 \mathrm{~min}$ & (3) $60 \mathrm{~min}$ & (4) in longer time & \\
\hline \multirow[t]{2}{*}{ Concentration difficulty } & (a) Yes & & & & (b) $\mathrm{No}$ \\
\hline & (1) $15 \mathrm{~min}$ & (2) $30 \mathrm{~min}$ & (3) $60 \mathrm{~min}$ & (4) in longer time & \\
\hline \multirow[t]{2}{*}{ Fatigue } & (a) Yes & & & & (b) $\mathrm{No}$ \\
\hline & (1) $15 \mathrm{~min}$ & (2) $30 \mathrm{~min}$ & (3) $60 \mathrm{~min}$ & (4) in longer time & \\
\hline \multirow[t]{2}{*}{ Dying sense } & (a) Yes & & & & (b) $\mathrm{No}$ \\
\hline & (1) $15 \mathrm{~min}$ & (2) $30 \mathrm{~min}$ & (3) $60 \mathrm{~min}$ & (4) in longer time & \\
\hline
\end{tabular}

version 22, IBM Corparation, Armonk, New York, United States).

A questionnaire was completed by the healthcare workers in the study. In addition to sociodemographic questions, 19 questions were asked about the cases that might arise after using a mask. The questions in the questionnaire have two options. In the questionnaire, the participants were asked to answer "Yes" to the questions if the case was observed after using the mask, and "No" if the case was not observed. Participants who answered "Yes" were asked when the phenomenon occurred. In the questionnaire, the participants were asked to choose one of the "not observed", "15 min",
"30 min", "60 min" and "longer" options according to the realization time of the case. In addition to the questionnaire questions directed at the participants, some clinical measurement values $\left(\mathrm{pH}, p \mathrm{CO}_{2}, \mathrm{HCO}_{3}, \mathrm{BE}, \mathrm{Lac}\right)$ were investigated after using the mask.

\section{Results}

Thirty-four participants were included in the study; 19 participants were female (56\%) and 15 male (44\%). The mean age of participants was $31.38 \pm 6.37$. There were $23(68 \%)$ 
Table 2 The survey and capillary blood gas after surgical mask

\begin{tabular}{|c|c|c|c|c|c|}
\hline \multirow{2}{*}{$\begin{array}{l}\text { Volunteer no } \\
\text { Capillary blood gas after } \\
\text { surgical mask }\end{array}$} & \multirow{2}{*}{$\begin{array}{l}\text { Weight } \\
\mathrm{pH}\end{array}$} & \multirow{2}{*}{$\begin{array}{l}\text { Height } \\
\mathrm{CO}_{2}\end{array}$} & \multicolumn{3}{|c|}{ Occupation: (1) doctor (2) nurse (3)staph } \\
\hline & & & $\mathrm{HCO}_{3}$ & $\mathrm{BE}$ & lactate \\
\hline \multirow[t]{2}{*}{ Headache } & (a) Yes & & & & (b) $\mathrm{No}$ \\
\hline & (1) $15 \mathrm{~min}$ & (2) $30 \mathrm{~min}$ & (3) $60 \mathrm{~min}$ & (4) in longer time & \\
\hline \multirow[t]{2}{*}{ Dizziness } & (a) Yes & & & & (b) $\mathrm{No}$ \\
\hline & (1) $15 \mathrm{~min}$ & (2) $30 \mathrm{~min}$ & (3) $60 \mathrm{~min}$ & (4) in longer time & \\
\hline \multirow[t]{2}{*}{ Palpitation } & (a) Yes & & & & (b) $\mathrm{No}$ \\
\hline & (1) $15 \mathrm{~min}$ & (2) $30 \mathrm{~min}$ & (3) $60 \mathrm{~min}$ & (4) in longer time & \\
\hline \multirow[t]{2}{*}{ Difficulty breathing } & (a) Yes & & & & (b) $\mathrm{No}$ \\
\hline & (1) $15 \mathrm{~min}$ & (2) $30 \mathrm{~min}$ & (3) $60 \mathrm{~min}$ & (4) in longer time & \\
\hline \multirow[t]{2}{*}{ Drowsiness } & (a) Yes & & & & (b) $\mathrm{No}$ \\
\hline & (1) $15 \mathrm{~min}$ & (2) $30 \mathrm{~min}$ & (3) $60 \mathrm{~min}$ & (4) in longer time & \\
\hline \multirow[t]{2}{*}{ Pins and needle } & (a) Yes & & & & (b) $\mathrm{No}$ \\
\hline & (1) $15 \mathrm{~min}$ & (2) $30 \mathrm{~min}$ & (3) $60 \mathrm{~min}$ & (4) in longer time & \\
\hline \multirow[t]{2}{*}{ Muscle cramps } & (a) Yes & & & & (b) $\mathrm{No}$ \\
\hline & (1) $15 \mathrm{~min}$ & (2) $30 \mathrm{~min}$ & (3) $60 \mathrm{~min}$ & (4) in longer time & \\
\hline \multirow[t]{2}{*}{ Nausea } & (a) Yes & & & & (b) $\mathrm{No}$ \\
\hline & (1) $15 \mathrm{~min}$ & (2) $30 \mathrm{~min}$ & (3) $60 \mathrm{~min}$ & (4) in longer time & \\
\hline \multirow[t]{2}{*}{ Vomiting } & (a) Yes & & & & (b) $\mathrm{No}$ \\
\hline & (1) $15 \mathrm{~min}$ & (2) $30 \mathrm{~min}$ & (3) $60 \mathrm{~min}$ & (4) in longer time & \\
\hline \multirow[t]{2}{*}{ Facial sweating } & (a) Yes & & & & (b) No \\
\hline & (1) $15 \mathrm{~min}$ & (2) $30 \mathrm{~min}$ & (3) $60 \mathrm{~min}$ & (4) in longer time & \\
\hline \multirow[t]{2}{*}{ Drowning sense } & (a) Yes & & & & (b) $\mathrm{No}$ \\
\hline & (1) $15 \mathrm{~min}$ & (2) $30 \mathrm{~min}$ & (3) $60 \mathrm{~min}$ & (4) in longer time & \\
\hline \multirow[t]{2}{*}{ Facial ichting } & (a) Yes & & & & (b) $\mathrm{No}$ \\
\hline & (1) $15 \mathrm{~min}$ & (2) $30 \mathrm{~min}$ & (3) $60 \mathrm{~min}$ & (4) in longer time & \\
\hline \multirow[t]{2}{*}{ Coughing } & (a) Yes & & & & (b) $\mathrm{No}$ \\
\hline & (1) $15 \mathrm{~min}$ & (2) $30 \mathrm{~min}$ & (3) $60 \mathrm{~min}$ & (4) in longer time & \\
\hline \multirow[t]{2}{*}{ Sneeze } & (a) Yes & & & & (b) $\mathrm{No}$ \\
\hline & (1) $15 \mathrm{~min}$ & (2) $30 \mathrm{~min}$ & (3) $60 \mathrm{~min}$ & (4) in longer time & \\
\hline \multirow[t]{2}{*}{ Attention deficit } & (a) Yes & & & & (b) $\mathrm{No}$ \\
\hline & (1) $15 \mathrm{~min}$ & (2) $30 \mathrm{~min}$ & (3) $60 \mathrm{~min}$ & (4) in longer time & \\
\hline \multirow[t]{2}{*}{ Concentration difficulty } & (a) Yes & & & & (b) $\mathrm{No}$ \\
\hline & (1) $15 \mathrm{~min}$ & (2) $30 \mathrm{~min}$ & (3) $60 \mathrm{~min}$ & (4) in longer time & \\
\hline \multirow[t]{2}{*}{ Fatigue } & (a) Yes & & & & (b) $\mathrm{No}$ \\
\hline & (1) $15 \mathrm{~min}$ & (2) $30 \mathrm{~min}$ & (3) $60 \mathrm{~min}$ & (4) in longer time & \\
\hline \multirow[t]{2}{*}{ Dying sense } & (a) Yes & & & & (b) $\mathrm{No}$ \\
\hline & (1) $15 \mathrm{~min}$ & (2) $30 \mathrm{~min}$ & (3) $60 \mathrm{~min}$ & (4) in longer time & \\
\hline
\end{tabular}

doctors, $9(26 \%)$ nurses and $2(6 \%)$ maintenance personnel (Table 3). Capillary blood gas analysis results were as follows: after N95 mask use, pH: 7.48 \pm 0.04 ; after surgical mask use, $\mathrm{pH}: 7.43 \pm 0.03$, the difference was statistically significant (paired $t$ test; $p<0.001$ ). $p \mathrm{CO}_{2}$ value was $28.46 \pm 7.77 \mathrm{mmHg}$ after N95 mask, $37.33 \pm 8.81 \mathrm{mmHg}$ after surgical mask, with the difference being statistically significant (paired $t$ test; $p<0.001$ ). $\mathrm{HCO}_{3}$ value was $23.73 \pm 3.29 \mathrm{mmol} / \mathrm{L}$ after $\mathrm{N} 95,24.92 \pm 2.86 \mathrm{mmol} / \mathrm{L}$ after surgical mask, the difference was not statistically significant (paired $t$ test; $p=0.113$ ). Base excess (BE) was -2.68
(- 4.50-1.20) after N95 and $1.40(-3.90-3.10)$ [median (Q1-Q3)] after surgical mask, the difference was statistically significant (Wilcoxon test, $p=0.039$ ). Lactate levels were not different $(1.74 \pm 0.68 ; 1.91 \pm 0.61$; paired $t$ test, $p=0.314$, respectively) (Table 4 ).

The survey filled out by the participants and statistical differences are shown in Tables 5 and 6. Accordingly, headache was present in 20 people (59\%) with N95 use and five people (15\%) with surgical mask use, the difference was statistically significant (McNemar test, $p=0.001$ ). There was no difference in terms of dizziness between 
Table 3 Demographical data of healthcare workers

\begin{tabular}{ll}
\hline Characteristics & \\
Age, mean \pm SD & $31.38 \pm 6.37$ \\
Weight, mean \pm SD & $72.43 \pm 17.23$ \\
Length, mean \pm SD & $1.69 \pm 0.08$ \\
BMI, mean \pm SD & $25.12 \pm 4.33$ \\
Sex & \\
Female, $n(\%)$ & $19(55.9)$ \\
Male, $n(\%)$ & $15(44.1)$ \\
Occupation & \\
Doctor, $n(\%)$ & $23(67.6)$ \\
Nurse, $n(\%)$ & $9(26.5)$ \\
Cleaning staff, $n(\%)$ & $2(5.9)$ \\
\hline
\end{tabular}

the participants $(p=0.070)$. While nine (27\%) participants complained of palpitations after the use of N95, no complaint of palpitations were observed after surgical mask use. Respiratory distress was observed in 27 (80\%) people after the use of N95. The same complaint was observed in eight (24\%) people after the use of surgical mask (McNemar test, $p=0.001)$. The feeling of dizziness, drowsiness was observed in $16(47 \%)$ people after the use of N95, and in two (6\%) people after surgical mask use (McNemar test, $p=0.001)$. Nausea was observed in four $(11 \%)$ people and vomiting in one after the use of N95, but these complaints were not seen following the use of a surgical mask. $18(53 \%)$ people experienced sweating on the face after N95 use, and $9(27 \%)$ after surgical mask use $(p=0.022)$. While $20(59 \%)$ participants felt like they were drowning after N95 use, only $2(6 \%)$ people had this experience after using a surgical mask $(p<0.001)$. There was no statistically significant difference in terms of itching, coughing and sneezing. Attention deficit was observed in 17 (50\%) people after N95, and in $5(15 \%)$ people after surgical mask use. Concentration problems were encountered in $21(62 \%)$ people after N95, and in $6(\% 18)$ people after surgical mask use $(p<0.001)$ (Figs. 1, 2). $21(62 \%)$ participants experienced fatigue after N95 use, and five (15\%) after surgical mask use $(p<0.001)$. Feelings of death were present in three $(9 \%)$ people after N95 use, and in one (3\%) person after surgical mask use $(p=0.5)$.

\section{Discussion}

In our study, we found that the capillary blood gas $\mathrm{pH}$ indicated alkalosis and $\mathrm{CO}_{2}$ was significantly low. In other words, respiratory alkalosis was detected in those using N95. In a study conducted during the COVID-19 pandemic, Ong et al. reported de novo PPE-associated headaches in $82 \%$ of healthcare workers (Ong et al. 2020). They expressed that the cause of de novo headache may be due to mechanical factors, hypoxemia, and hypercarbia. In a survey study conducted with nurses wearing PPE, they detected headache in $50 \%$ of the participants wearing N95 masks (Atay and Cura 2020). In another study on the use of N95 during the SARS epidemic, Lim et al. reported headache in $37.3 \%$ of participants after N95 use and linked this finding to the increased amount of inhaled $\mathrm{CO}_{2}$ (Lim et al. 2006). In another study, it has been suggested that the use of filtering facepiece masks may lead to $\mathrm{CO}_{2}$ retention; these findings were supported with laboratory studies (Roberge et al. 2010; Wu et al. 2011). On the contrary; in our study, $\mathrm{CO}_{2}$ was significantly lower with the use of N95 compared to surgical mask, and hypocarbia was observed. Hypocarbia leads to bronchodilation and pulmonary vasodilation. Respiratory alkalosis shifts the oxyhemoglobin curve to the left and reduces oxygen delivery to tissues (Hopper 2017; Okonjo 2015). Hypocarbia causes cerebral vasoconstriction and decreased intracranial pressure (Lumb 2010; Sharma and Hashmi 2020). In addition, respiratory alkalosis may cause a decrease in ionized calcium concentration (Lopez et al. 2003). In some patients, acute arteriolar alkalosis causes vasoconstriction and cardiac arrhythmias, confusion and seizures may develop with decreased cerebral and myocardial perfusion. Headache, attention deficit, concentration problems in employees may be due to cerebral vasoconstriction due to acute alkalosis. Alkalosis causes potassium to shift into the cell, and hypokalemia can cause neuromuscular weakness, arrhythmias, and polyuria (Johnson 2017). In this context, the current study
Table 4 Comparison of capillary blood gas analysis between N95 mask and surgical mask

\begin{tabular}{llll}
\hline & Surgical mask & N95 mask & $p$ \\
\hline $\mathrm{pH}$, mean $\pm \mathrm{SD}$ & $7.43 \pm 0.03$ & $7.48 \pm 0.04$ & $<0.001^{*}$ \\
$p \mathrm{CO}_{2}$, mean $\pm \mathrm{SD}$ & $37.33 \pm 8.81$ & $28.46 \pm 7.77$ & $<0.001^{*}$ \\
$\mathrm{HCO}_{3}$, mean $\pm \mathrm{SD}$ & $24.92 \pm 2.86$ & $23.73 \pm 3.29$ & 0.131 \\
$\mathrm{BE}^{\mathrm{b}}$, median $(\mathrm{Q} 1-\mathrm{Q} 3)$ & $1.40(-3.90-3.10)$ & $-2.68(-4.50-1.20)$ & $0.039^{*}$ \\
$\mathrm{LAC}$, mean $\pm \mathrm{SD}$ & $1.91 \pm 0.61$ & $1.74 \pm 0.68$ & 0.314 \\
\hline
\end{tabular}

Paired $t$ test, $\alpha: 0.05$

*Statistical significance

${ }^{\mathrm{b}}$ Wilcoxon test 
Table 5 Frequencies of physical and psychological symptoms between N95 mask and surgical mask

\begin{tabular}{|c|c|c|c|c|c|c|c|c|c|c|}
\hline \multirow{2}{*}{$\begin{array}{l}\text { Physical and psycho- } \\
\text { logical symptoms }\end{array}$} & \multicolumn{2}{|l|}{ No } & \multicolumn{2}{|c|}{$15 \mathrm{~min}$} & \multicolumn{2}{|c|}{$30 \mathrm{~min}$} & \multicolumn{2}{|c|}{$60 \mathrm{~min}$} & \multicolumn{2}{|c|}{$>60 \min$} \\
\hline & $n$ & $\%$ & $n$ & $\%$ & $n$ & $\%$ & $n$ & $\%$ & $n$ & $\%$ \\
\hline \multicolumn{11}{|l|}{ Headache } \\
\hline N95 mask & 14 & $(41.2)$ & 2 & (5.9) & 9 & $(26.5)$ & 6 & $(17.6)$ & 3 & (8.8) \\
\hline Surgical mask & 29 & $(85.3)$ & 0 & $(0.0)$ & 0 & $(0.0)$ & 1 & (2.9) & 4 & (11.8) \\
\hline \multicolumn{11}{|l|}{ Dizziness } \\
\hline N95 mask & 26 & (76.5) & 1 & (2.9) & 2 & (5.9) & 3 & $(8.8)$ & 2 & (5.9) \\
\hline Surgical mask & 32 & $(94.1)$ & 0 & $(0.0)$ & 0 & $(0.0)$ & 0 & $(0.0)$ & 2 & (5.9) \\
\hline \multicolumn{11}{|l|}{ Palpitation } \\
\hline N95 mask & 25 & $(73.5)$ & 1 & (2.9) & 3 & $(8.8)$ & 5 & $(14.7)$ & 0 & $(0.0)$ \\
\hline Surgical mask & 34 & $(100.0)$ & 0 & $(0.0)$ & 0 & $(0.0)$ & 0 & $(0.0)$ & 0 & $(0.0)$ \\
\hline \multicolumn{11}{|l|}{ Difficulty breathing } \\
\hline N95 mask & 7 & $(20.6)$ & 8 & $(23.5)$ & 9 & $(26.5)$ & 8 & $(23.5)$ & 2 & (5.9) \\
\hline Surgical mask & 26 & $(76.5)$ & 1 & $(2.9)$ & 2 & $(5.9)$ & 0 & $(0.0)$ & 5 & $(14.7)$ \\
\hline \multicolumn{11}{|l|}{ Drowsiness } \\
\hline N95 mask & 18 & $(52.9)$ & 3 & (8.8) & 5 & $(14.7)$ & 5 & $(14.7)$ & 3 & (8.8) \\
\hline Surgical mask & 32 & $(94.1)$ & 0 & $(0.0)$ & 0 & $(0.0)$ & 0 & $(0.0)$ & 2 & (5.9) \\
\hline \multicolumn{11}{|l|}{ Pins and needle } \\
\hline N95 mask & 32 & $(94.1)$ & 1 & (2.9) & 1 & (2.9) & 0 & $(0.0)$ & 0 & $(0.0)$ \\
\hline Surgical mask & 34 & $(100.0)$ & 0 & $(0.0)$ & 0 & $(0.0)$ & 0 & $(0.0)$ & 0 & $(0.0)$ \\
\hline \multicolumn{11}{|l|}{ Muscle cramps } \\
\hline N95 mask & 34 & (100.0) & 0 & $(0.0)$ & 0 & $(0.0)$ & 0 & $(0.0)$ & 0 & $(0.0)$ \\
\hline Surgical mask & 33 & $(97.1)$ & 0 & $(0.0)$ & 0 & $(0.0)$ & 0 & $(0.0)$ & 1 & (2.9) \\
\hline \multicolumn{11}{|l|}{ Nausea } \\
\hline N95 mask & 30 & $(88.2)$ & 1 & $(2.9)$ & 1 & (2.9) & 0 & $(0.0)$ & 2 & (5.9) \\
\hline Surgical mask & 33 & $(97.1)$ & 1 & $(2.9)$ & 0 & $(0.0)$ & 0 & $(0.0)$ & 0 & $(0.0)$ \\
\hline \multicolumn{11}{|l|}{ Vomiting } \\
\hline N95 mask & 33 & $(97.1)$ & 0 & $(0.0)$ & 1 & (2.9) & 0 & $(0.0)$ & 0 & $(0.0)$ \\
\hline Surgical mask & 34 & $(100.0)$ & 0 & $(0.0)$ & 0 & $(0.0)$ & 0 & $(0.0)$ & 0 & $(0.0)$ \\
\hline \multicolumn{11}{|l|}{ Facial sweating } \\
\hline N95 mask & 16 & $(47.1)$ & 8 & $(23.5)$ & 6 & (17.6) & 4 & (11.8) & 0 & $(0.0)$ \\
\hline Surgical mask & 25 & $(73.5)$ & 2 & (5.9) & 2 & (5.9) & 2 & (5.9) & 3 & $(8.8)$ \\
\hline \multicolumn{11}{|l|}{ Drowning sense } \\
\hline N95 mask & 14 & $(41.2)$ & 7 & $(20.6)$ & 6 & (17.6) & 6 & (17.6) & 1 & (2.9) \\
\hline Surgical mask & 31 & $(91.2)$ & 1 & $(2.9)$ & 1 & (2.9) & 0 & $(0.0)$ & 1 & (2.9) \\
\hline \multicolumn{11}{|l|}{ Facial itching } \\
\hline N95 mask & 25 & $(73.5)$ & 4 & $(11.8)$ & 2 & (5.9) & 2 & (5.9) & 1 & (2.9) \\
\hline Surgical mask & 26 & $(76.5)$ & 0 & $(0.0)$ & 2 & (5.9) & 3 & (8.8) & 3 & (8.8) \\
\hline \multicolumn{11}{|l|}{ Coughing } \\
\hline N95 mask & 27 & (79.4) & 2 & $(5.9)$ & 3 & (8.8) & 1 & (2.9) & 1 & $(2.9)$ \\
\hline Surgical mask & 31 & $(91.2)$ & 1 & $(2.9)$ & 0 & $(0.0)$ & 1 & (2.9) & 1 & $(2.9)$ \\
\hline Sneeze & & & & & & & & & & \\
\hline N95 mask & 30 & $(88.2)$ & 2 & $(5.9)$ & 1 & (2.9) & 0 & $(0.0)$ & 1 & $(2.9)$ \\
\hline Surgical mask & 33 & $(97.1)$ & 0 & $(0.0)$ & 1 & (2.9) & 0 & $(0.0)$ & 0 & $(0.0)$ \\
\hline Attention deficit & & & & & & & & & & \\
\hline N95 mask & 17 & $(50.0)$ & 4 & $(11.8)$ & 3 & (8.8) & 7 & (20.6) & 3 & (8.8) \\
\hline Surgical mask & 29 & $(85.3)$ & 0 & $(0.0)$ & 2 & (5.9) & 2 & (5.9) & 1 & $(2.9)$ \\
\hline Concentration difficul & & & & & & & & & & \\
\hline N95 mask & 13 & $(38.2)$ & 5 & $(14.7)$ & 5 & $(14.7)$ & 7 & $(20.6)$ & 4 & $(11.8)$ \\
\hline Surgical mask & 28 & (82.4) & 0 & $(0.0)$ & 2 & (5.9) & 3 & $(8.8)$ & 1 & $(2.9)$ \\
\hline
\end{tabular}


Table 5 (continued)

\begin{tabular}{|c|c|c|c|c|c|c|c|c|c|c|}
\hline \multirow{2}{*}{$\begin{array}{l}\text { Physical and psycho- } \\
\text { logical symptoms }\end{array}$} & \multicolumn{2}{|c|}{ No } & \multicolumn{2}{|c|}{$15 \mathrm{~min}$} & \multicolumn{2}{|c|}{$30 \mathrm{~min}$} & \multicolumn{2}{|c|}{$60 \mathrm{~min}$} & \multicolumn{2}{|c|}{$>60 \mathrm{~min}$} \\
\hline & $n$ & $\%$ & $n$ & $\%$ & $n$ & $\%$ & $n$ & $\%$ & $n$ & $\%$ \\
\hline \multicolumn{11}{|l|}{ Fatigue } \\
\hline N95 mask & 13 & $(38.2)$ & 3 & $(8.8)$ & 4 & $(11.8)$ & 4 & $(11.8)$ & 10 & $(29.4)$ \\
\hline Surgical mask & 28 & $(82.4)$ & 0 & $(0.0)$ & 1 & $(2.9)$ & 3 & (8.8) & 2 & (5.9) \\
\hline \multicolumn{11}{|l|}{ Dying sense } \\
\hline N95 mask & 31 & $(91.2)$ & 1 & $(2.9)$ & 0 & $(0.0)$ & 0 & $(0.0)$ & 2 & $(5.9)$ \\
\hline Surgical mask & 33 & $(97.1)$ & 0 & $(0.0)$ & 0 & $(0.0)$ & 0 & $(0.0)$ & 1 & $(2.9)$ \\
\hline
\end{tabular}

showed that the symptoms in the participants were due to respiratory alkalosis and hypocarbia.

In a study with the NIOSH Automated Breathing and Metabolic Simulator (ABMS) device, Sinkule and colleagues reported that the average inhaled $\mathrm{CO}_{2}$ decreased in FFR as well as FFR with surgical mask, and the amount of inhaled $\mathrm{O}_{2}$ increased with respect to increased oxygen consumption (Sinkule et al. 2013). Another study showed that with the use of N95, there was increased respiratory resistance and this quantitatively and objectively disrupted the nasal airflow (Lee and de Wang 2011).

According to our survey results; the use of N95 significantly increased the rates of headache, respiratory distress, drowsiness, and feeling of numbness compared to surgical masks. The main research topic of our study was dizziness, but no difference was observed between N95 and surgical mask use in this regard. As previously mentioned, the participants stated that they felt significantly greater attention deficit and difficulty concentrating with N95 use compared to surgical mask. When we reviewed the literature, we found that the questionnaires generally inquire the level of comfort, and no studies have been performed regarding attention deficit and concentration difficulties due to the use of N95 face mask (Or et al. 2018; Roberge et al. 2010). In another study reported lower heart rate and less discomfort in those who wore a surgical face mask than those who wore a N95 mask (Li et al. 2005). In this sense, we believe that although being subjective, no scale was used in the present study, and it contributed to the literature. In their study, Coca et al. reported that using protective equipment caused heatstroke and suggested that appropriate working and resting times should be established to avoid undesired side effects (Coca et al. 2017). To ensure employee comfort, we believe that rest times should be created at appropriate intervals and symptoms related to N95 use should be reduced.

\section{Limitations of the study}

The study has several limitations. The small number of subjects is one of the limitations of our study. The fact that ionized calcium was not included in our study is another limitation of the study. In terms of being standard, one model of N95 and surgical mask was utilized in the study. It may be more convenient to wear surgical and other types of masks versus N95. Capillary blood gases were measured after the mask was removed. It could be better to measure every 15 min with the mask on. Subjective information about attention deficit and difficulty concentrating was provided. These can be made more objective with standard tests and scales. It will be more convenient to conduct the study on a larger population and with consideration to the limitations specified. 
Table 6 Comparison of physical and psychological symptoms between N95 mask and surgical mask

\begin{tabular}{l}
$\begin{array}{l}\text { Physical and psychologi- } \\
\text { cal symptoms }\end{array}$ \\
\hline
\end{tabular}

\begin{tabular}{|c|c|c|}
\hline Headache $^{\mathrm{a}}$ & & \\
\hline No, $n(\%)$ & $14(41.2)$ & $29(85.3)$ \\
\hline Yes, $n(\%)$ & $20(58.8)$ & 5 (14.7) \\
\hline Dizziness $^{\mathrm{a}}$ & & \\
\hline No, $n(\%)$ & $26(76.5)$ & $32(94.1)$ \\
\hline Yes, $n(\%)$ & $8(23.5)$ & $2(5.9)$ \\
\hline Palpitation $^{\mathrm{a}}$ & & \\
\hline No, $n(\%)$ & $25(73.5)$ & $34(100.0)$ \\
\hline Yes, $n(\%)$ & $9(26.5)$ & $0(0.0)$ \\
\hline Difficulty breathing ${ }^{a}$ & & \\
\hline No, $n(\%)$ & $7(20.6)$ & $26(76.5)$ \\
\hline Yes, $n(\%)$ & $27(79.4)$ & $8(23.5)$ \\
\hline Drowsiness $^{\mathrm{a}}$ & & \\
\hline No, $n(\%)$ & $18(52.9)$ & $32(94.1)$ \\
\hline Yes, $n(\%)$ & $16(47.1)$ & $2(5.9)$ \\
\hline Pins and needle & & \\
\hline No, $n(\%)$ & $32(94.1)$ & $34(100.0)$ \\
\hline Yes, $n(\%)$ & $2(5.9)$ & $0(0.0)$ \\
\hline Muscle cramps $^{\mathrm{a}}$ & & \\
\hline No, $n(\%)$ & $34(100.0)$ & $33(97.1)$ \\
\hline Yes, $n(\%)$ & $0(0.0)$ & $1(2.9)$ \\
\hline Nausea & & \\
\hline No, $n(\%)$ & $30(88.2)$ & $34(100.0)$ \\
\hline Yes, $n(\%)$ & $4(11.8)$ & $0(0.0)$ \\
\hline Vomiting $^{\mathrm{a}}$ & & \\
\hline No, $n(\%)$ & $33(97.1)$ & $34(100.0)$ \\
\hline Yes, $n(\%)$ & $1(2.9)$ & $0(0.0)$ \\
\hline Facial sweating $^{\mathrm{a}}$ & & \\
\hline No, $n(\%)$ & $16(47.1)$ & $25(73.5)$ \\
\hline Yes, $n(\%)$ & $18(52.9)$ & $9(26.5)$ \\
\hline
\end{tabular}
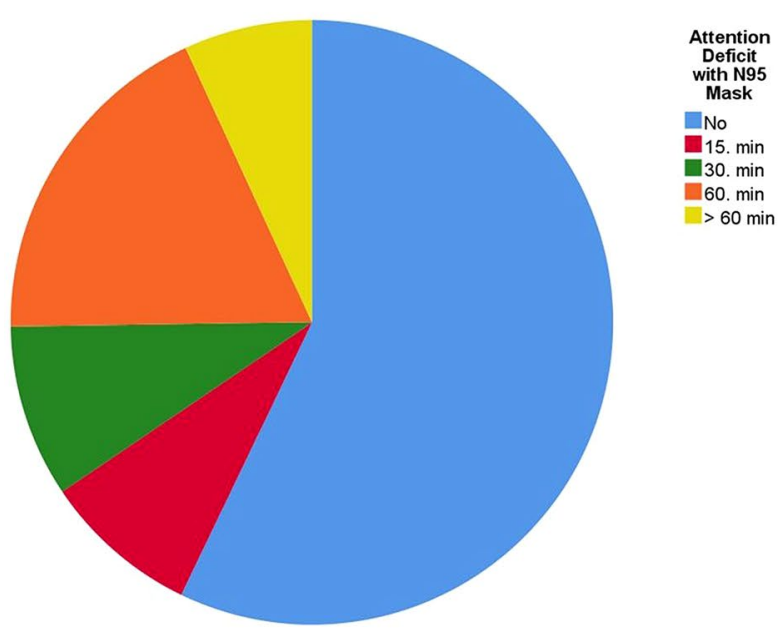

Table 6 (continued)

Physical and psychologi- N95 mask $\quad$ Surgical mask $p$
cal symptoms

\begin{tabular}{|c|c|c|c|}
\hline Drowning sense $^{\mathrm{a}}$ & & & $<0.001^{*}$ \\
\hline No, $n(\%)$ & $14(41.2)$ & $32(94.1)$ & \\
\hline Yes, $n(\%)$ & $20(58.8)$ & $2(5.9)$ & \\
\hline Facial itching $^{\mathrm{a}}$ & & & $1.00^{\mathrm{c}}$ \\
\hline No, $n(\%)$ & $25(73.5)$ & $26(76.5)$ & \\
\hline Yes, $n(\%)$ & $9(26.5)$ & $8(23.5)$ & \\
\hline Coughing $^{\mathrm{a}}$ & & & $0.125^{\mathrm{b}}$ \\
\hline No, $n(\%)$ & $27(79.4)$ & $31(91.2)$ & \\
\hline Yes, $n(\%)$ & $7(20.6)$ & $3(8.8)$ & \\
\hline Sneeze $^{\mathrm{a}}$ & & & $0.250^{\mathrm{b}}$ \\
\hline No, $n(\%)$ & $30(88.2)$ & $33(97.1)$ & \\
\hline Yes, $n(\%)$ & $4(11.8)$ & $1(2.9)$ & \\
\hline Attention deficit ${ }^{\mathrm{a}}$ & & & $<0.001 *$ \\
\hline No, $n(\%)$ & $17(50.0)$ & $29(85.3)$ & \\
\hline Yes, $n(\%)$ & $17(50.0)$ & $5(14.7)$ & \\
\hline Concentration difficulty ${ }^{\mathrm{a}}$ & & & $<0.001 *$ \\
\hline No, $n(\%)$ & $13(38.2)$ & $28(82.4)$ & \\
\hline Yes, $n(\%)$ & $21(61.8)$ & $6(17.6)$ & \\
\hline Fatigue $^{\mathrm{a}}$ & & & $<0.001^{*}$ \\
\hline No, $n(\%)$ & $13(38.2)$ & $29(85.3)$ & \\
\hline Yes, $n(\%)$ & $21(61.8)$ & $5(14.7)$ & \\
\hline Dying sense $^{\mathrm{a}}$ & & & $0.500^{\mathrm{b}}$ \\
\hline No, $n(\%)$ & $31(91.2)$ & $33(97.1)$ & \\
\hline Yes, $n(\%)$ & $3(8.8)$ & $1(2.9)$ & \\
\hline
\end{tabular}

*Statistical significance

${ }^{\mathrm{a}} \mathrm{McNemar}$ test, $\alpha$ : 0.05

${ }^{\mathrm{b}}$ Binomial distribution

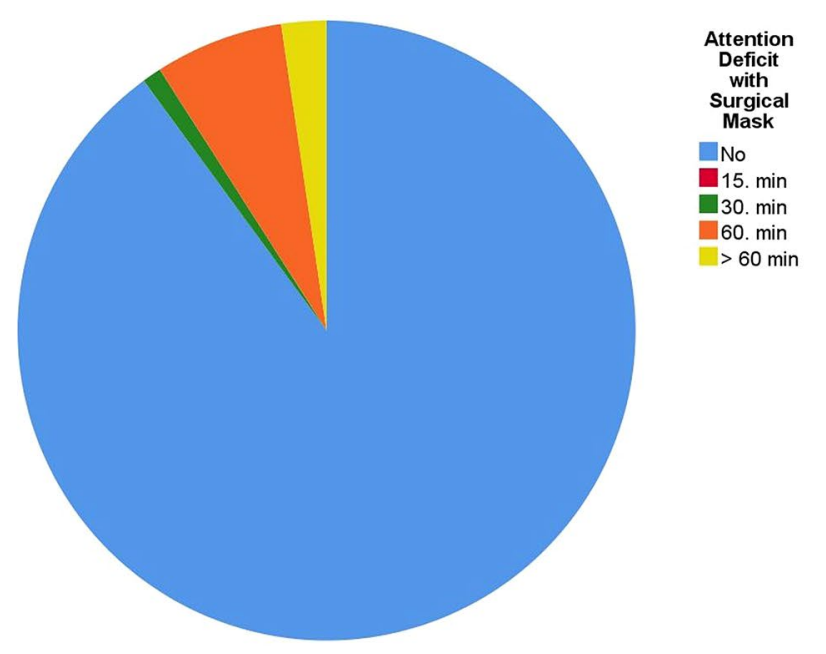

Fig. 1 Attention deficit with N95 mask 

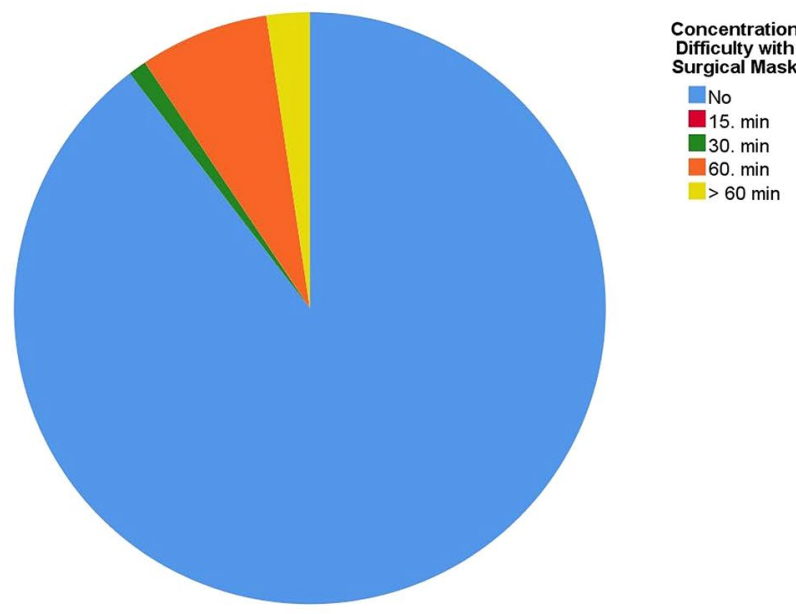

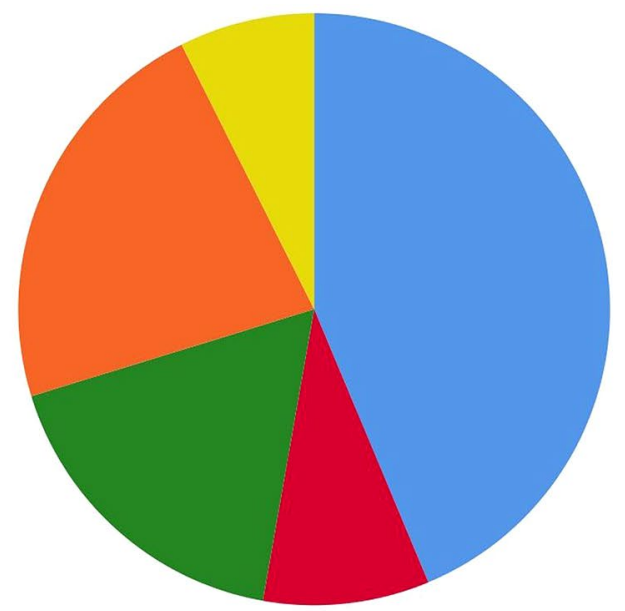
Difficulty with
N95 Mask No ㄴ. 15. min -30. $\min$ 60. $\mathrm{min}$ $>60 \mathrm{~min}$

Fig. 2 Concentration difficulty with N95 mask

Author contributions Sİ wrote the manuscript. Sİ and AD analysed the data. UUG, SY, TD and CA collected the data. SI and UUG reviewed the results and provided guidelines for presentation and interpretation. All the authors have read and approved the final manuscript.

Funding The authors have not declared a specific grant for this research from any funding agency in the public, commercial or notfor-profit sectors.

Data availability All relevant data and materials are presented in the paper.

\section{Compliance with ethical standards}

Conflict of interest None declared.

Ethical approval This study was approved by the Ethics Committee of Kahramanmaraş Sütçü İmam Üniversitesi, Medical Faculty.

Informed consent Consent for publication was obtained.

\section{References}

Atay S, Cura Ş (2020) Problems encountered by nurses due to the use of personal protective equipment during the Coronavirus pandemic: results of a survey. Wound Manag Prev 66:12-16

Coca A, Quinn T, Kim JH, Wu T, Powell J, Roberge R, Shaffer R (2017) Physiological evaluation of personal protective ensembles recommended for use in West Africa. Disaster Med Pub Health Prep 11:580-586. https://doi.org/10.1017/dmp.2017.13

Cucinotta D, Vanelli M (2020) WHO declares COVID-19 a pandemic. Acta Bio Med Atenei Parm 91:157

Hopper K (2017) Respiratory acid-base disorders in the critical care unit. Vet Clin N Am Small Anim Pract 47:351-357. https://doi. org/10.1016/j.cvsm.2016.09.006
Johnson RA (2017) A quick reference on respiratory alkalosis. Vet Clin N Am Small Anim Pract 47(181):184. https://doi. org/10.1016/j.cvsm.2016.10.005

Lee HP, de Wang Y (2011) Objective assessment of increase in breathing resistance of N95 respirators on human subjects. Ann Occup Hyg 55:917-921. https://doi.org/10.1093/annhyg/mer065

Li Y, Tokura H, Guo YP, Wong AS, Wong T, Chung J, Newton E (2005) Effects of wearing N95 and surgical facemasks on heart rate, thermal stress and subjective sensations. Int Arch Occup Environ Health 78:501-509. https://doi.org/10.1007/ s00420-004-0584-4

Li Q et al (2020) Early transmission dynamics in Wuhan, China, of novel Coronavirus-infected pneumonia. New Engl J Med 382:1199-1207. https://doi.org/10.1056/NEJMoa2001316

Lim EC, Seet RC, Lee KH, Wilder-Smith EP, Chuah BY, Ong BK (2006) Headaches and the N95 face-mask amongst healthcare providers. Acta Neurol Scand 113:199-202. https://doi.org/10. 1111/j.1600-0404.2005.00560.x

Lopez I, Rodriguez M, Felsenfeld AJ, Estepa JC, Aguilera-Tejero E (2003) Direct suppressive effect of acute metabolic and respiratory alkalosis on parathyroid hormone secretion in the dog. J Bone Miner Res 18:1478-1485. https://doi.org/10.1359/ jbmr.2003.18.8.1478

Lumb A (2010) Changes in the carbon dioxide partial pressure. Nunn's applied respiratory physiology. Elsevier, Toronto

Okonjo KO (2015) Bohr effect of hemoglobins: accounting for differences in magnitude. J Theor Biol 380:436-443. https://doi. org/10.1016/j.jtbi.2015.06.021

Ong JJY et al (2020) Headaches associated with personal protective equipment-a cross-sectional study among frontline healthcare workers during COVID-19. Headache 60:864-877. https://doi. org/10.1111/head.13811

Or PP, Chung JW, Wong TK (2018) A study of environmental factors affecting nurses' comfort and protection in wearing N95 respirators during bedside procedures. J Clin Nurs 27:e1477-e1484. https://doi.org/10.1111/jocn.14268

Roberge RJ, Coca A, Williams WJ, Palmiero AJ, Powell JB (2010) Surgical mask placement over N95 filtering facepiece respirators: physiological effects on healthcare workers. 
Respirology (Carlton, Vic) 15:516-521. https://doi.org/10.111 $1 /$ j.1440-1843.2010.01713.x

Sharma S, Hashmi MF (2020) Hypocarbia. StatPearls Publishing LLC., Treasure Island

Sinkule EJ, Powell JB, Goss FL (2013) Evaluation of N95 respirator use with a surgical mask cover: effects on breathing resistance and inhaled carbon dioxide. Ann Occup Hyg 57:384-398. https://doi. org/10.1093/annhyg/mes068

Sohrabi C et al (2020) World Health Organization declares global emergency: a review of the 2019 novel coronavirus (COVID-19). Int J Surg (London, England) 76:71-76. https://doi.org/10.1016/j. ijsu.2020.02.034
World Health Organization (2020): Coronavirus Disease (COVID2019) Situation Report 107. Geneva, Switzerland, World Health Organization. https://www.who.int/emergencies/diseases/novel -coronavirus-2019/situation-reports. Accessed 6 May 2020

Wu S, Harber P, Yun D, Bansal S, Li Y, Santiago S (2011) Anxiety during respirator use: comparison of two respirator types. J Occup Environ Hyg 8:123-128. https://doi.org/10.1080/15459 624.2011 .549780

Publisher's Note Springer Nature remains neutral with regard to jurisdictional claims in published maps and institutional affiliations. 